\title{
A Comparative Analysis of Selected Fundamentals of Christianity and Islam.
}

\author{
Author: $\quad$ ONI, Idris Ajani \\ Email: $\quad$ idrisrasaq@gmail.com \\ Tel: $\quad$ 07065200336, 08050434167 \\ Institution: $\quad$ Olabisi Onabanjo University, Ago-Iwoye, Ogun State. \\ OrcID Number: 0000-0003-2730-6424
}

\begin{abstract}
Prominent among religions that claim direct or indirect lineage to Abraham are Judaism, Christianity and Islam. The three religions are known as monotheistic. Although, their interpretations of monotheism are closely similar, they have salient differences. Such differences have spurred unhealthy arguments, rivalry and hatred between some Christians and Muslims.
\end{abstract}

Thus, this paper highlights some of the basic differences between Islam and Christianity traceable to scriptural differences and interpretations and the causes of disagreement between Christianity and Islam with a view to offering recommendations that would foster goodwill and engender better relationship between Christians and Muslims.

The paper adopted a comparative and analytical system of research with library information and experiences as the major data gathering tools.

The study finds that misinformation, ignorance, deliberate distortions, media irresponsibility among others is the major causes of disharmony among Christians and Muslims. The paper recommends mutual love and respect, constant dialogue, education and other factors that would improve the attitude of Christians and Muslims towards one another.

\section{Keywords: Religion, Islam, Christianity, Abrahamic, Dialogue}

\section{Introduction}

Abrahamic faiths are the world religions whose claims, origins or practices are directly linked to Abraham (Prophet Ibrāhīm - AS). The most popular and popular and populous Abrahamic religions are Judaism, Christianity and Islam. While Judaism relies on the traditions of Moses (Prophet Mūsā - AS), Christianity follows the path of Jesus (Prophet 'Īsā) and Islam follows the teachings of Prophet Muhammad and other Prophets and Messengers before him (AS) as instructed in the Glorious Qur'ān 2: 285. 
Nevertheless, Islam and Christianity have shared a rivalry that is not limited by time or space. In prints and television debates, scholars of Christianity and Islam have engaged in dialogue and arguments to prove the superiority of one faith over the other. On several occasions, arguments on faith especially among non-professionals have been misconstrued and led to violent conflict, blackmail, and stigmatisation. This paper aims at discussing some of the issues that highlight the similarities and dissimilarities between Christianity and Islam with a view to engendering mutual respect and dialogue among adherents of both faiths. This follows the clear indication stipulated in the Glorious Qur'ān 11: 118.

The verse of the Qur'ān quoted above accurately informs the notion that the differences they have are part of the divine design of Almighty God. Therefore, in the cause of studying the differences, scholars of religion must emphasise that the differences should not divide or cause enmity among the adherents. In addition, scholars must emphasise the areas of similarity and make efforts to promote mutual respect, love and dialogue because the centre focus of all Abrahamic religions is God. Said et.al (2004) fittingly capture this idea when they wrote:

....we should look to the rich and vivid truths shared by the Abrahamic traditions and their conceptualization of the role of knowledge and education as a purposeful, ordered quest for meaning and beauty. These three traditions honour a God that sought to be 'known'.

Religion, race and tribe are only means for the identification of classes, groups and categories of people that God Almighty created. This is well entrenched in all the Abrahamic religious texts, notably also in the Glorious Qur'ān 49: 13. Therefore, this paper discusses the areas of agreement and disagreement among the Abrahamic faiths with a particular focus on the prominent Abrahamic faiths in Nigeria, Christianity and Islam. The major equilibrium points of the two religions are:
a. Monotheism
b. Teachings on ethics and morality
c. Body of beliefs such as the belief in hell and paradise
d. Mutual love and respect

The major areas of friction among them are: 
a. The interpretation of monotheism (theology) and;

b. Politics

\section{Similarities between Christianity and Islam}

As noted above, Christianity and Islam have links to Abraham who is revered and honoured among Christians and Muslims alike. The two faiths share certain basic and fundamental aspects of belief, which further proves the link that they share with Prophet Abraham. Among such fundamentals are:

\section{a. Monotheism}

Monotheism is the belief in the existence of only One God Who is known as the Master, Creator, Provider, the Almighty and General-Manager of all that exists. According to www.study.com (2018), "monotheism is a style of religious belief that asserts the existence of only one God. This may seem straightforward, but different religions interpret this in different ways". Asserting the place of monotheism in Christianity, the Bible says:

You alone are the LORD You have made the heavens, The heaven of heavens with all their host, The earth and all that is on it, The seas and all that is in them You give life to all of them And the heavenly host bows down before You (Nehemiah 9:6).

The Qur'ān also repeatedly affirms the Oneness of God (Allah) as the central theme of Islamic teaching. Majority of its verses are direct or indirect pointers to a strict, incorruptible monotheism. One of such verses is:

Allah (God) is He Who raised the heavens without any pillars that you can see. Then, He Istawā (rose above) the Throne (really in a manner that suits His Majesty). He has subjected the sun and the moon (to continue going round), each running (its course) for a term appointed. He regulates all affairs, explaining the $\bar{A} y \bar{a} t$ (proofs, evidences, verses, lessons, signs, revelations, etc.) in detail that you may believe with certainty in the meeting with your Lord (Glorious Qur'ān 13: 2).

Similarly, the Holy Bible, Deuteronomy 6: 4 reports that Jesus (AS) said: "Hear, O Israel! The Lord is our God, the Lord is one". In addition, the Exodus 20: 2-17 states: 
I am the Lord your God, who brought you out of the land of Egypt, out of the house of slavery, you shall have no other gods before me. You shall not make for yourself an idol, whether in the form of anything that is in heaven above, or that is on the earth beneath, or that is in the water under the earth. You shall not bow down to them or worship them; for I the Lord your God am a jealous God (Pontifical Biblical Commission, 2018).

Hence, monotheism is a central theme to both Christianity and Islam. This fundamental aspect of monotheism (God's indivisible unity) is principally shared by all Abarahamic faiths notwithstanding the theological arguments on the interpretation of God's unity among Jews, Muslims and Christians and the various perceptions that emerged with the growth of the human age. While Judaism and Islam are seen as strict monotheistic faiths, Christianity is considered a liberal monotheism due to its concept of trinity (a concept that underlines the major source of friction between Muslims and Christians).

While Christianity presents Jesus as a part of the God's head (the son), revere and worship him as "God" or "Saviour" or "Messiah", most scholars of Islam considers the trinity and representation of God in human bodily in a way that depicts Him as a person (anthropomorphism) acts of polytheism and blasphemy. Nonetheless, Islam mandates all Muslims to believe in Jesus. Islam also places Jesus in an undeniable place among other Prophets and Messengers of God. Islam emphasises that the source of the teachings and messages of the Prophets including Jesus and Muhammad are the same i.e. God. A Muslim ceases to be a believer immediately he insults Jesus or claim disbelief in his miraculous birth or his message for the Israelites.

Hence, the context of the message though similar across board, the conception of Jesus among the three prominent religions particularly Islam and Christianity differs. The subject of "Jesus" in relation to trinity and monotheism is the underlining factor in the Judeo Christian - Islamic dichotomy.

\section{b. Teachings on ethics and morality}

Christianity and Islam espouse the significance of morality and ethics. Their holy scriptures contain lessons on morality, God's consciousness and good human relationships. Islam consciously divides the tenets of faith into three namely Isläm (submission to Allah), 
Iman (faith), Ihsān (righteousness). Both religions frown at social vices and in some cases provide stern punishments for impunity against the divine laws contained in the Scriptures or communicated by the Prophets. Hence, on the teachings of morality and ethics, Islam and Christianity are united. Among the many verses of the Qur'ān that exhort humankind to morality are:

It is not righteousness that you turn your faces towards East or West; but it is righteousness (the quality of ) the one who believes in God and the Last Day and the Angels, and the Book, and the Messengers; who spends of his wealth, in spite of love for it, to the kinsfolk, to the orphans, to the needy, to the wayfarer, to those who ask and for the freeing of slaves; and who is steadfast in prayers, and gives Zakah (Alms); and those who fulfil their covenants which they made; and who are patient and perseverant in poverty and ailment and throughout all periods of fighting. Such are the people of truth, the pious (Qur'ān 2: 177).

The Bible also lays emphasis on morality as an integral part of righteousness and belief in God. For example, First Corinthians 15: 33 says: "Do not be deceived: "Bad company ruins good morals". Mark 7: 20-23 also says:

What comes out of a person is what defiles him. For from within, out of the heart of man, come evil thoughts, sexual immorality, theft, murder, adultery, coveting, wickedness, deceit, sensuality, envy, slander, pride, foolishness. All these evil things come from within, and they defile a person.

Therefore, Christianity and Islam are similar in their teachings on morality and righteousness.

\section{c. Eschatology (Heaven and Hell; Life after death)}

While Christianity and Islam interpret monotheism as well as other body of beliefs differently, there remains a striking resemblance in their understanding and teachings of morality and faith in connection with eternal punishment in hellfire or paradise for evil and good doers respectively. There are variant opinions on the interpretation of life after death in Christianity. Some believe that death enables the soul to return to God (its Owner), the body 
is laid to a rest similar to sleep (as in the case of Lazarus) until the appointed time for rapture or judgment as the case may be. Other Christian denominations believe that immediately after death, the soul is placed in its rightful place i.e. hell or paradise (Bibleinfo.com, 2018).

Islam teaches that the body houses the soul but the soul is an ever-living creature. It lives perpetually even after the death of the body. Islam emphasises that the proceedings of judgment begins immediately one is deceased. Hence, from the deathbed to the grave and to the day of resurrection and final judgment, Islam affirms that humankind receive rewards or punishment of/for their deeds.

While Christianity affirms rapture for the followers of Christ, Islam affirms the intercession of Prophet Muhammad for Muslims on the Day of Judgment. Qur'ān 7: 172173 states:

And [mention] when your Lord took from the children of Adam - from their loins - their descendants and made them testify of themselves, [saying to them], "Am I not your Lord?" They said, "Yes, we have testified." [This] - lest you should say on the day of Resurrection, "Indeed, we were of this unaware."

Or [lest] you say, "It was only that our fathers associated [others in worship] with Allah before, and we were but descendants after them. Then would You destroy us for what the falsifiers have done?"

Therefore, the belief in resurrection and judgment is a common tenet in Islam and Christianity albeit the differences in narrations or accounts of prophecies given in Islam and Christian traditions.

\section{d. Mutual love and respect}

Mutual love and respect are cardinal points in Christianity and Islam. Islam recognises Christians and Jews as People of the Scriptures, made marriage with them permissible and their food Halāl (lawful) for Muslims. In cases where specific instructions were given to Muslims not to take Jews and Christians as ally, evidences have shown that those were in 
response to the hypocrisy of certain elements within the Christian and Jewish community at the time of revelation. In relation to this, the Glorious Qur'ān 60: 8 says:

God does not forbid you from being good to those who have not fought you in the religion or driven you from your homes or from being just towards them. God loves those who are just.

Hence, enmity with Jews and Christians is not an institution in Islam. Enmity is established only against those who reneged on agreements made with the Muslims and joined the idolaters against them. Islam also recognises the wisdom of God (Allah) in the creation of humans with different races, colours and beliefs. He therefore enjoined love, goodness and righteousness. The Qur'ān 5: 48 says:

We have appointed a law and a practice for every one of you. Had God willed, He would have made you a single community, but He wanted to test you regarding what has come to you. So compete with each other in doing good. Every one of you will return to God and He will inform you regarding the things about which you differed.

Through numerous verses of the Glorious Qur'ān and Prophetic traditions, Islam emphasises mutual understanding, love and good inter-personal relationship as obligations for the faithful. It is important to also note here that Islam specifically emphasises good relationship with Christians. The Glorious Qur'ān 5:82-86 says:

Strongest among men in enmity to the believers wilt thou find the Jews and Pagans; and nearest among them in love to the believers wilt thou find those who say, "We are Christians": because amongst these are men devoted to learning and men who have renounced the world, and they are not arrogant. And when they listen to the revelation received by the Apostle, thou wilt see their eyes overflowing with tears, for they recognise the truth: they pray: "Our Lord! we believe; write us down among the witnesses. What cause can we have not to believe in God and the truth which has come to us, seeing that we long for our Lord to admit us to the company of the righteous?" And for this their prayer hath God rewarded them with gardens, with rivers flowing underneath,- their eternal home. Such is the recompense of those who do good. But those who reject 
Faith and belie our Signs,- they shall be companions of Hell-fire.

In the same vein, Christian traditions also emphasise love and mutual respect. Notable among Biblical teachings on this subject are:

Honour all people. Love the brotherhood. Fear God. Honour the king. Servants, be submissive to your masters with all fear, not only to the good and gentle, but also to the harsh" (1 Peter 2:17-18); "He who does not love does not know God, for God is love" (1 John 4:8; compare 1 John 2:9-11).

Therefore, despite the differences in Christian-Muslim interpretations of some salient topics in faith, they both emphasise the need to love one's neighbour as one loves himself irrespective of the latter's faith. This concept often re-echoes in the moral and spiritual teachings of all the Abrahamic faiths.

\section{Some of the sources of disagreement between Christianity and Islam}

Christianity and Islam differ in some aspects and to certain degrees. Their disagreements are usually products of their differing theological interpretations or politics. This section discusses the causes of friction between Islam and Christianity.

\section{a. Theological friction}

As noted earlier, Christianity is built on monotheism with trinity as its vertebrate and nucleus as most Christians believe. Although, some Christian denominations and Muslims reject trinity and consequently termed it polytheism, majority of the Christian world promotes and strongly hold trinity in high esteem. Under the theological differences between Islam and Christianity are the following:

\section{i. The place of Abraham}

Abraham holds an inestimable position in both Islam and Christianity. Christians refer to him as the "father of faith" while Muslims refer to him as Abūnā Ibrāhìm (our father, Abraham). According to Christian and Islamic sources, Abraham was the father of Isaac (the ancestor of Jesus) and Ismā' $\mathbf{l}$ (the ancestor of Prophet Muhammad). Abraham was referred to as Hanīfan-Musliman (a sincere Muslim) in the Glorious Qur'ān 22: 78. The attribute 
aptly detached him from being a Jew or a Christian as Glorious Qur'ān 3: 67. The verse reads:

Abraham was not a Jew nor yet a Christian; but he was true in Faith (Hanifan-Musliman - one who bowed his will to Allah's), and he joined not gods with Allah.

Some people believe that Islam started with Prophet Muhammad or that he was the founder of Islam. Islamic traditions teach that Islam is a single religion that came in phases; the phases were completed and made wholesome and perfected by Prophet Muhammad as the last Prophet of God on earth. Islam establishes the place of Abraham as one of the first persons to be called "Muslim" (Qur'ān 6: 163; 39: 12). It consciously reiterates the significance of believing in all Prophets and Messengers of God, starting with Adam, Enoch, Noah, Abraham, Moses, Jesus, Muhammad and others.

Christianity also reveres Abraham and holds him in high esteem. The Holy Bible like the Glorious Qur'ān gives enormous account of Abraham's life and personality and presents him as the symbol of faith. However, discrepancies in the narratives of Abraham stemmed from the story of the sacrificial-child (Dhabih). The Holy Bible states that Isaac (the son of Sarah) was the chosen child whom was to be used as a sacrifice to God but was replaced with a ram. The Glorious Qur'ān 37: 99-113 give an account that renders Ismā'̄̂l rather than Ishāq as the sacrificial-child. Islamic traditions also hold that both Ismā'̄̄l and Ishāq were chosen as Prophets of God and blessed. Alongside Abraham, Ismā'īl also had the honour of building the Ka'abah which a symbol of faith for all Muslims until the end of the world (Qur'ān 2: 127). Hence, the Christian-Muslim rivalry along the Isaac/Ishmael argument began is one that conspicuously divides them.

\section{ii. Interpretation and understanding of the divinity of Jesus}

Muslims and Christians share belief in the divine birth and life of Jesus. However, while Islam holds Jesus in high esteem as one of the greatest Prophets and Messengers of God, many Christians consider him the very essence of God. Islam prohibits the veneration or worship of any being except God and strongly condemns the Christians' belief in trinity and the worship of Jesus as God or a part of God's divinity in Glorious Qur'ān 5: 73. 
The belief in Jesus' divinity is the basis of most dissimilarities between Islam and Christianity. While the Qur'ān constantly condemned trinity as polytheism, Christians constantly promote as many believe that it is the core of the true faith in God Almighty as the Holy Bible suggests in John 14: 6: "Jesus saith unto him, I am the way, the truth, and the life: no man cometh unto the Father, but by me".

Hence, arguments and questions of who is right and who is not emerge. The questions have led to hot theological arguments and thousands of books have been written by adherents of both religions as well as freethinkers to bicker in favour of each belief or lend their voices or ideas for or against either of the two interpretations. History shows that religious wars such as the Crusades of the 11th and 12th centuries stemmed from religious beliefs and politics. The argument lingers and remains the major cause of disagreement among adherents of the Abrahamic faiths. The Qur'ānic account goes thus:

[Jesus] said, "Indeed, I am the servant of Allah. He has given me the Scripture and made me a prophet. And He has made me blessed wherever I am and has enjoined upon me prayer and Zakah as long as I remain alive. And [made me] dutiful to my mother, and $\mathrm{He}$ has not made me a wretched tyrant. And peace is on me the day I was born and the day I will die and the day I am raised alive." That is Jesus, the son of Mary - the word of truth about which they are in dispute. It is not [befitting] for Allah to take a son; exalted is He! When He decrees an affair, He only says to it, "Be," and it is (Qur'ān 19: 30 -32).

Joining the Muslims and Jews in the belief that Jesus is not God or a part of God's divinity are: the Unitarians (also called non-Trinitarians), Jehovah Witnesses, Mormons, Christian scientists, Armstronogists (followers of Herbert W. Armstrong, 1934, the founder of Philadelphia Church of God, Global Church of God, United Church of God), Christadelphians, Oneness Pentecostals, Unification adherents (Unification adherents believe that God is positive and negative, male and female. The universe is God's body, made by him. Jesus was not God, but a man), Scientologists and so on (Fairchild, 2017).

\section{iii.Crucifixion}

The death of Christ on the cross of Calvary is one the most important themes of the Christian faith. Christianity teaches that Jesus died on the cross for the forgiveness and 
eternal salvation of humankind. The account of his death as the Holy Bible renders it goes thus:

When they had crucified him, they divided his clothes by throwing dice. Then they sat down and kept guard over him there. Above his head they put the charge against him, which read: "This is Jesus, the king of the Jews." Then two outlaws were crucified with him, one on his right and one on his left. Those who passed by defamed him, shaking their heads and saying: "You who can destroy the temple and rebuild it in three days, save yourself! If you are God's Son, come down from the cross!" In the same way even the chief priests - together with the experts in the law and elders - were mocking him: "He saved others, but he cannot save himself! He is the king of Israel! If he comes down now from the cross, we will believe in him! He trusts in God-let God, if he wants to, deliver him now because he said, 'I am God's Son'!" The robbers who were crucified with him also spoke abusively to him.

Now from noon until three, darkness came over all the land. At about three o'clock Jesus shouted with a loud voice, "Eli, Eli, lema sabachthani?" that is, "My God, my God, why have you forsaken me?" When some of the bystanders heard it, they said, "This man is calling for Elijah." Immediately one of them ran and got a sponge, filled it with sour wine, put it on a stick, and gave it to him to drink. But the rest said, "Leave him alone! Let's see if Elijah will come to save him." Then Jesus cried out again with a loud voice and gave up his spirit (Mathew 27: 35 50) (Deffinbaugh, 2005).

However, Islam debunks the claims of death on the cross. The Glorious Qur'ân clearly states that Jesus was neither killed nor crucified (Qur'ān 4: 157 - 159).

And [for] their saying, "Indeed, we have killed the Messiah, Jesus, the son of Mary, the messenger of Allah". And they did not kill him, nor did they crucify him; but [another] was made to resemble him to them. And indeed, those who differ over it are in doubt about it. They have no knowledge of it except the following of assumption. And they did not kill him, for certain. Rather, Allah raised him to Himself. And ever is Allah Exalted in Might and Wise. And there is none from the People of the Scripture but that he will surely believe in Jesus (as God or son of God or a 
part of God's divinity) before his death. And on the Day of Resurrection he will be against them a witness.

For rejecting the death of Christ on the cross for the salvation of humankind, many Christians consider Muslims as unbelievers. Hence, the constant need to evangelize not only the pagans but the Muslims as well. Sam Shamoun, the renowned Christian critique argues for Jesus' death on the cross when he wrote:

The crucifixion, death, and resurrection of Jesus Christ is the heart of the Christian faith. Everything a Christian believes in and hopes for revolves around Jesus' death on the cross for unworthy sinners. The resurrection is the divine vindication of the fact that Jesus did not die for any crime he had committed, but died in place of sinners needing redemption and justification before an infinitely holy and just God. If it can be proven that Jesus did not die and rise from the dead, then Christianity is nothing more than a great lie, which has deceived literally billions throughout the ages. The Christian is left without hope, having no assurance of justification, and remains in his sins (1 Corinthians 15:12-19; Romans 4:25, 5:8-11).

\section{iv. Jesus' concept of "son of God"}

While the Holy Bible presents Jesus as the son of God and son of man alternatively, the Glorious Qur'ān constantly refers to him as the son of Mary and warned sternly against ascribing a son or children to God or comparing Him to any visible or imaginable picture of a being as a reprehensive abomination. Glorious Qur'ān 4: 171 reads:

O followers of the Gospel! Do not overstep the bounds [of truth] in your religious beliefs, and do not say of God anything but the truth. The Christ Jesus, son of Mary, was but God's Apostle - [the fulfilment of] His promise which He had conveyed unto Mary - and a soul created by Him. Believe, then, in God and His apostles, and do not say, "[God is] a trinity". Desist [from this assertion] for your own good. God is but One God; utterly remote is He, in His glory, from having a son: unto Him belongs all that is in the heavens and all that is on earth; and none is as worthy of trust as God. 
Also Qur'ān 6: 101; 9: 30; 10: 68; 17: 111; 18: 4; 19: 35, 88 - 92; 21:26; 23: 91; 37: 152; 39: 4; 43: $81-82 ; 72: 3$ and 112: 1 - 4 reiterate this belief. In the Holy Bible, some of the narratives of the sonship of Jesus are:

When all things are subjected to Him, then the Son Himself also will be subjected to the One who subjected all things to Him, so that God may be all in all. 1 Corinthians 15:28

"I will surely tell of the decree of the LORD: He said to Me, 'You are My Son, Today I have begotten You. Psalm 2:7

For to which of the angels did He ever say, "you are my son, today i have begotten you"? And again, "i will be a father to him and he shall be a son to me"? Hebrews 1-5 (Knowingjesus.com, 2018).

It is pertinent to note that the Bible also referred to the believers as children of God. For example:

'He shall build a house for My name, and he shall be My son and I will be his father; and I will establish the throne of his kingdom over Israel forever.' (1 Chronicles 22:10).

"He said to me, 'Your son Solomon is the one who shall build My house and My courts; for I have chosen him to be a son to Me, and I will be a father to him. (1 Chronicles 28:6).

Now there was a day when the sons of God came to present themselves before the LORD, and Satan also came among them. (Job 1:6).

Again, there was a day when the sons of God came to present themselves before the LORD, and Satan also came among them to present himself before the LORD. (Job 2:1).

Islam rejects both the literal usage of the phrase "child of God" and its contextual interpretations. Thus, it teaches that Muslims must refer to themselves only as servants of God. Qur'ān 19: 93 says: "There is no one in the heavens and earth but that he comes to the Most Merciful as a servant".

\section{v. The Antichrist}


Islamic and Christian traditions have similar reports on the prophecy of the apocalypse, which includes the emergence of the Antichrist. However, Islam presents the Antichrist (Dajjāl) as a one-eyed evil man that shall emerge towards the end of the world; live for only forty days which shall be tougher than forty years due to the pains and atrocities that the Antichrist shall afflict on the people of faith. Islam teaches that the Antichrist would falsely lay claims to prophethood and have many followers across the world. The Christian theory on the apocalypse presents the Antichrist as a person or group of persons or institutions that do not ally with the Christians in their faith or beliefs. It presents the Antichrist as antiChristians and anti-Christianity.

This understanding erroneously places Muslims (who many Christians see as an opposing side or disbelievers to the person or message of Christ) in the position of the Antichrist. Therefore, in many professional Christian texts, Prophet Muhammad is represented win the image of an Antichrist and Muslims as followers of an Antichrist (Nata, 2015). Hence, many Church leaders teach congregants that Muhammad was an impostor and a false Prophet. The following quotation attests to such claims.

The Koran (al-Qur'ān), the book of Islam, is not only the testimony of a false prophet but also the testimony of Antichrist. Yet so many hearing that testimony today are willing to believe it, to take it to heart, to stand on it, and even to die for it as if it were written by the Spirit of Truth (Pearson, 2018).

It is worthy of note that Islamic primary traditions or sources consistently affirms that the Antichrist shall appear towards the end of time as one of the greatest signs of the end of the world and would be followed by multitudes as he would claim to be the expected Comforter. At this time, the Antichrist (Dajjāl) and his followers shall commit recordbreaking atrocities, the likes of which had never happen. Islam also affirms that at that time, Jesus ('Isā) would return to the world to fight against the Antichrist, stop the consumption of pigs and destroy crosses (which Islam and Judaism consider a symbol of polytheism and falsehood).

\section{vi. Divinity of the Holy Bible and Glorious Qur'ān}


Another major area of friction is the Christian claim that the Glorious Qur'ān is an inspiration from a demon or a directly copied document from Judeo-Christian sources. It is an argument that Christian and Jews have sustained for many centuries. The Glorious Qur'ān itself remains the only book in the history of humankind whose author has challenged the entire world of humankind and Jinn to disprove its claims or present verses similar to its own. It says:

And if you are in doubt about what We have sent down upon Our Servant [Muhammad], then produce a surah the like thereof and call upon your witnesses other than Allah, if you should be truthful (Qur'ān 2: 23).

Scientists, archaeologists, thinkers, have done many treatises and great research works and writers from other fields of study have written for or against the divinity of the Glorious Qur'ān. Majority of such writers, scientists and thinkers came out convinced that the Qur'ān can only be a divine revelation. Gathered here are quotations from some notable writers and researchers about the Qur'ān:

The Koran admittedly occupies an important position among the great religious books of the world. Though the youngest of the epoch-making works belonging to this class of literature, it yields to hardly any in the wonderful effect which it has produced on large masses of men. It has created an all but new phase of human thought and a fresh type of character. It first transformed a number of heterogeneous desert tribes of the Arabian Peninsula into a nation of heroes, and then proceeded to create the vast politico-religious organisations of the "Muhammadan" world which are one of the great forces with which Europe and the East have to reckon today.

G Margoliouth quoted from Introduction to J.M. Rodwell's The Koran, New York: Everyman's Library, 1977, p. VII.

A work, then, which calls forth so powerful and seemingly incompatible emotions even in the distant reader - distant as to time, and still more so as mental development - a work which not only conquers the repugnance which he may begin its perusal, but changes this adverse feeling into astonishment and admiration, such a work must be a wonderful production of the human mind )Editor's note: The Quran is not the production of the human mind, but a 
revelation from Allah Almighty) indeed and a problem of the highest interest to every thoughtful observer of the destinies of mankind.

Dr. Steingass, quoted in T.P. Hughes' Dictionary of Islam, pp. 526-7.

The above observation makes the hypothesis advanced by those who see Muhammad as the author of the Quran untenable. How could a man, from being illiterate, become the most important "author", in terms of literary merits, in the whole of Arabic literature? How could he then pronounce truths of a scientific nature that no other human being could possibly have developed at that time, and all this without once making the slightest error in his pronouncement on the subject?

Maurice Bucaille as quoted from: The Bible, the Quran and Science, 1978, p. 125.

Similarly, Muslims strongly believe that the Bibles in circulation today are either not the ideal representatives or narratives of the Holy Gospel (Injīl) commissioned for Jesus ('Īsā). This accusation often rattles the foundation of Christianity and often causes hatred between the two parties. Muslims and Islam have questioned the authenticity of the present day Christianity on the basis of the differences between the old and new testaments vis-à-vis other divine scriptures i.e. Glorious Qur'ān and Torah.

Steven Cowan, a prominent Associate Professor of Philosophy and Apologetics at Southeastern Bible College in Birmingham, Alabama explained briefly the meaning of the sentence "The Bible is the word of God". He writes:

Christians throughout the centuries have claimed much more for Scripture than that it is historically reliable, consistent, and truthful. We have claimed that the Bible is the Word of God. That is, we believe that God is the (ultimate) author of the sixty six books of the Protestant canon. Despite the real authorial input of the human writers, the very words (graphē) of the biblical autographs find their origin in the mind of God (2 Tim 3:16). As Peter put it, "Moved by the Holy Spirit, [they] spoke from God" (2 Pet 1:21 NLT). In ways that may be difficult or impossible to explain (and we will not attempt to explain it here), God worked providentially in the lives of the human authors, and sometimes spoke directly to them, so that the 
words they wrote were his words. This is what Christians mean when they say that the Bible is divinely inspired (Steven, 2005).

Muslims, Christian researchers and others have constantly questioned that claim alike. Although, Islam emphasises the importance of the scriptures and Prophets that came before the Glorious Qur'ān and Prophet Muhammad, it also constantly debunks some of the claims made in the Holy Bible and refers to the Injīl (the Gospel) as the original scripture of Jesus Christ. Today, it is believed that the Holy Bible (old and new testaments) contains a mixture of the word of God and stories or narratives of men, which have led to the corruption of the Holy Bible and the faith it represents. Usually, the Injīl is regarded as a "lost scroll".

The Glorious Qur'ān confirms the messages and scriptures that were revealed before Prophet Muhammad repetitively but also warned of distortions and twisting that it alleges had occurred over the books overtime.

O you who were given the Scripture, believe in what We have sent down [to Muhammad], confirming that which is with you, before We obliterate faces and turn them toward their backs or curse them as We cursed the Sabbathbreakers. And ever is the decree of Allah accomplished (Qur'ān 4: 47).

Querying the authenticity of the Qur'ān and its clams, Bj (nd) notes:

How could the God who preserved the Quran be incapable of preserving His Injil and Taurat. Is He not all powerful? If a book is the Word of God, variant readings and copyist errors would not negate the divine authority. But how shall they make thee their judge, since they possess already the Law (Taurat), in which are the behests of God? ... Verily, we have sent down the law (Taurat) wherein are guidance and light, 5:47,48. ... and we gave him (Jesus) the Evangel (Injil) with its guidance and light, confirmatory of the preceding Law (Taurat); a guidance and warning to those who fear God; - and that the people of the Evangel (Injil) may judge according to what God hath sent down - such are the perverse. And to thee we have sent down the Book of the Koran with truth, confirmatory of previous Scriptures, and their safeguard. ...To every one of you have we given a rule and a beaten track. And if God had pleased He had surely made you all one people; but He would test you by what He hath given to each.... 5:50-55. 
Jay (nd) also questioned the authenticity of the Qur'ān when he writes:

From there we dealt with the claim by Muslims that Qur'anic authority is found in the miracle of its composition; that it has superior and unique literary qualities, which exceed any known written work. It seems to be the consensus of a number of scholars, however, that with no logical connection from one sura to the next, the Qur'an not only is difficult to read, its content is so confusing that it takes an enormous amount of patience to understand it. With criticisms like these it is difficult to understand why Muslims continue to elevate its supposed literary qualities. We noted that Muslims claim the Qur'an a universal document. Yet, we found the Qur'an to be a uniquely 7th-9th century Arab piece of literature, which reflected the mentality and culture of that time. This was made clear with two examples: the case for the inferiority of women and the profoundly violent nature of the Qur'an and its prophet, Muhammad. From there we continued to the collection of the original documents, asking the question of whether any document which comes from the hands of God could be tampered with as we have witnessed here in these examples. The incredible respect and awe which is evidenced by Muslims today for their Qur'an belies the seemingly cavalier attitude of the earlier Caliphs towards the original codices, evidenced by their burning of all extent manuscripts, even those which Muhammad himself had deemed to be authoritative....

Of the authenticity of the Bible, it says in 2Timothy 3:16-17:

All scripture is God breathed and is useful for correcting, for doctrine, for reproof, for instruction and for training in all righteousness.

However, the authenticity of the Bible also has been put to scrutiny. Barron (2016), a licensed minister in the Missionary Baptist tradition writes:

The Holy Bible is a collection of Christian texts that is the result of refinement by men who thought they were led by God to discern his teachings. The early Christian world was diverse and everyone had a different take on the Gospel of Jesus. These disagreements were "settled" in large meetings of high ranking priests called "Councils." The Council of Hippo (one of the African Synods) drew up a collection of texts, which is now the Catholic Bible (including a class of texts I as a Protestant would call 
Apocrypha), in 393 AD. St. Jerome is credited with creating the Old Latin Vulgate, which was the outcome of the African Synods and was used as the Bible for centuries. The Bible's last book to be penned was the Book of Revelation of John of Patmos in the late 80's early 90's AD. The first compilation of cannon did not come about until about three hundred years later at the Council of Hippo. The iconic (though fictional) scene of Martin Luther nailing his Ninety-Five Theses to the church door until October 31,1517, over a millennium after the composition of the Vulgate. The Kings James Version would make its debut in the year of 1611 (before the letter J existed, so the name "Jesus" did not appear once). Presently, I struggle to accept this book (a couple of iterations later) as the unadulterated word of God.

Hence, there will always be the questions of what is and what not the word of God is but for the believers who are supposedly truly convinced about the Holy Bible and Glorious Qur'ān, only thorough research, education and sincerity can lead to the light of truth. Consequently, it should not cause disrespect, hatred or enmity as the true essence of faith is love and humanity. However, the accusation and counter accusations of forgeries and falsification, which have rattled the world of the faithful and caused frequent stir and endless enmity and in most cases, utter disrespect from professionals and non-professionals alike may inevitably remain a plague. It is therefore important for adherents of both faiths to accept that the two scriptures are inherently unique in their own perspectives. While studies are encouraged, respect and decorum as taught by both Books must always be put to practice. The differences between the Glorious Qur'ān and Holy Bible cited by Thomas Schirrmacher in his work The Koran and the Bible are enough proofs that there may never be an agreement on the accuracy or inaccuracy of the two Holy books from the views of each opposing sides. Hence, respect is inestimably pivotal.

\section{c. Politics}

Another major factor in the cause of the rift between Christians and Muslims is politics. Politics has played prominent roles in creating a dichotomy between Christians and Muslims especially in Nigeria. Adherents of each religion from past to present are trained with the desire to establish a system of government that recognises God as the Supreme source of power and rule. Hence, Christianity has been used as a state religion and source of political 
power by the Romans, Crusaders and others. Christian colonial masters also entrenched Christianity as an official religion of the conquered nations and promoted Christian values through constitutions and education. Similarly, the Qur'ān exhorts Muslims to establish the law of Allah (God) on earth. Hence, Islam since it emerged a state religion in Madinah in the 7th century continues to spread and challenge existing authorities economically, socially and most importantly, politically.

Hence, both Islam and Christianity consider politics sine-qua-non in the propagation of faith and the spread of their beliefs. Hence, the struggle for political power or systemic dominance becomes imperative especially in multi-religious states like Nigeria. Consequently, through the use of religion for political gains, adherents of Islam and Christianity have often been set against one another, properties and lives have been lost as mischievous politicians constantly hide behind religion to instigate citizens and cause crisis. Asserting this fact, Afolabi (2015) states:

....It (religion) is being used as an instrument of oppression
and deceit in Nigeria. It appears that Nigerians have
resigned themselves to fate and this is possibly further
compounded by poverty, illiteracy, and lack of political
education on the part of majority....

Nigeria as a nation recognises the role of religion in power sharing, thus the federal character purportedly always require an equal representation of Christian and Muslims as well all major ethnic nationalities in governance. In nations such as Lebanon, political power is shared among Muslims, Christians and citizens who are adherents of other faiths in the country. In other nations like the United States of America, France and United Kingdom, Islamophobic rhetoric has been used for political purposes. The consequent effect of that is more hate and hate crimes. In worst scenarios like the Bosnia, Muslims have been slaughtered for only being Muslims. The recent mass murder and persecution of Muslims in Burma as well as the mass murder in Australia are proofs of the role that Islamophobia is playing in world's crises.

Media has also played a significant role in the cause of disharmony among Muslims and Christians especially in Nigeria. Factors that fan hatred and disharmony also include: arguments on the ownership of Jerusalem, extremism and terrorism, misrepresentation of the 
faiths, misinformation, ignorance and close-mindedness, blind followership and so on. Deliberate attempt to malign, disrespect and stir up misconceptions and misrepresentation of other groups through the media and supposed academic works are also prominent factors in the cause of friction between Christians and Muslims. Among such blackmailing and untrue information can be found in the works of Peter O. Awojobi titled Conflict between Christians and Muslims with reference to northern Nigeria; Anees Zaka and Diane Coleman's work The truth about Islam: The Noble Quran teachings in the light of the Holy Bible and a host of others. The works do not only contain fallacies about Islam, they also defeated scholasticism, misinform the public and disrespect the many truthful and honest Christian professionals.

\section{Recommendations}

Abrahamic faiths have closely related history and teachings. Therefore, they are closest to one another in faith than the pagans and idolaters can ever be. They also constitute over half of the total world population, a fact that makes it compulsory for them to find a common ground to jointly save and preserve the world. To achieve a lasting peace in the world and better relations among adherents of the Abrahamic faiths, this paper recommends:

a. mutual love and respect;

b. regular inter-religious dialogue and inter-religious education;

c. training of religious leaders and preachers to stand for the humanity;

d. an agreement on a proportionate share of power and a system of ruling in multireligious nations that allows adequate representation of people of different faiths and protect collective interests;

e. a very stern response against hate speeches and misinformation and/or deliberate misrepresentation and ill presentation of others by some groups of a faith and so on.

\section{Conclusion}

The human races have the same origin and root according to the three notable Abrahamic faiths. This automatically makes every man the brother of another. Although, the source of the prominent Abrahamic religions particularly Christianity and Islam is the will of Allah (God), Christians and Muslims would always differ. However, the differences should only reveal their uniqueness and never be a reason for hatred and bloodshed). Therefore, this 
research presents recommendations for engendering mutual respect and better relationship between Christians and Muslims.

\section{References}

Afolabi, O. (2015). The role of religion in Nigerian politics and its sustainability for political development. Net Journal of Social Sciences. 3(2), 42-49. Institute of African Studies, University of Ibadan, Nigeria.

Bibleinfo.com (2018). What happens after death? Retrieved from: http://www.bibleinfo.com/en/questions/what-does-bible-say-about-death.

Barron, A. (2016). Why the Bible Is Not the Word of God. Retrieved from: https://www.huffingtonpost.com/alexander-j-barron/why-the-bible-is-not-theb $7717552 . h$ tml.

Bj T. (nd). Is the Quran the word of God? Retrieved from: http://www.brigada.org/wpcontent/uploads/2014/06/Is the_Q the word_of_God. pdf.

Deffinbaugh R. (2005). The Day Christ Died (Matthew 27:32-61). Retrieved from: https://bible.org/seriespage/day-christ-died-matthew-2732-61.

Study.com (2018). Monotheism. Retrieved from:

https://study.com/academy/lesson/monotheism-in-judaism-definition-historyquiz.html.

Fairchild, M. (2017). Faith Groups That Reject the Trinity Doctrine a Brief Explanation of Religions That Deny the Doctrine of the Trinity.

Retrieved from: https://www.thoughtco.com/faith-groups-that-reject-trinitydoctrine-700367.

Islamweb.net (2018). What they say about the Quran. Retrieved from: 
http://www.islamweb.net/en/article/134281/what-they-say-about-the-quran.

Jay, S. (nd). The Qur'ān (A Christian Apologetic). Retrieved from: http://radicaltruth.net/uploads/The_Quran-A_Christian_Apologetic.pdf.

Nata R. (2015). 50 Proofs Muhammad is the antichrist. Retrieved from: http://richardnata.blogspot.co.id/2015/10/50-proofs-muhammad-isantichrist $95 . \mathrm{html}$.

Pearson A., (2018). The Koran (al-Qur'an)Testimony of Antichrist. Tennessee, United States: Christ Evangelical Bible Institute.

Pontifical Biblical Commission (2018). The Bible and Morality Biblical Roots of Christian Conduct. Retrieved from: http://www.vatican.va/roman_curia/congregations/cfaith/pcb_documents/rc con cfaith_doc_20080511_bibbia-e-morale_en.html.

Qur'ān.com (nd). Translations of the meanings of the Qur'ān. Retrieved from: https://quran.com/.

Said, A., Marshall K., John, R., Elcott, D., Abdalla, A., Alkhayat, H., Goodpaster, K., Weiss, J., (2004). The Principles of the Abrahamic Faiths: Traditions that Advance Education. Washington, DC: Creative Associates International and the Caux Round Table. International Trade Center.

Schirrmacher T. (2013). The Koran and the Bible. World of Theology Series. (7). Germany: Theological Commission of the World Evangelical Alliance.

Steven, C. (2000). Bible is God's Word? 241-89, 374-80; Kelly James Clark, "Reformed Epistemology Apologetics," in Cowan, Five. New York: Oxford University Press.

Sunnah.com (2018). The Hadith of the Prophet Muhammad (صلى الله عليه و سلم) at your fingertips. Retrieved from: https://sunnah.com Wissenschaft Culture and Science Publication. Germany.

Verlag für Kultur und Shamoun S. (nd). The Crucifixion of Christ - A Christian Critique of the Quran.

Retrieved from: http://www.answering-islam.org/Shamoun/crucifixion.htm

Wellman J., (2015). Top 7 Bible Verses About Morality. Retrieved from: http://www.patheos.com/blogs/christiancrier/2015/06/23/top-7-bible-versesabout- morality/ 